\title{
LXIV. Additional observations for the purpose of ascertaining the value of growing timber at different and distant periods of time
}

\author{
Mr. Charles Waistell
}

To cite this article: Mr. Charles Waistell (1810) LXIV. Additional observations for the purpose of ascertaining the value of growing timber at different and distant periods of time, Philosophical Magazine Series 1, 35:146, 428-431, DOI: 10.1080/14786441008563118

To link to this article: http://dx.doi.org/10.1080/14786441008563118

曲 Published online: 18 May 2009.

Submit your article to this journal $\pi$

Џll Article views: 2

Q View related articles $\sqsubset$ 
neither bran nor malt for mashes, which were ordered for the horses with sulphur, after bleeding: That he ordered the men to cut furze, and ordered them to give it to the horses, after they had beat it well on the pavement: that at first they had to mix it with oats, but that in two days the horses devoured it like clover. That by these means he recovered them all, though every other troop lost two or three; and that his was the only troop in good condition at the review. I remain with esteem, sir, Your sincere and humble servant,

Muirficld, Jan. E2, 1869. TO C. TAYLOR, M.D. Sec. Spencer Cochrane.

LXIV. Additional Observations for the Purpose of ascertaining the Value of growing Timber at different and distant Periods of Time. By Mr. Charles Waistell, of High Holburn, London *.

$\mathrm{S}_{\mathrm{IR}}, \mathbf{I}_{\mathbf{N}}$ the Society's last volume, under the head of Agriculture, are some tables and observations of mine, on the

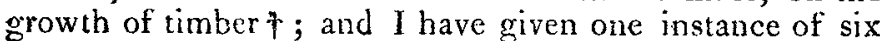
acres of very bad land, planted with Scotch firs under my directions, which at 29 years growth, and at the small price of $1 s$. a foot, had paid the owner $5 l$. per acre per annum compound interest. My motive in communicating these tables, observations and facts to the public, was to promote the planting of inferior and almost useless soils, in, order to obtain from them timber of-our own growth, sufficient for at lcast many of the purposes for which foreign timber is imported at an immense annual expense. For instance, much of such inferior soils will be found on Connock Heath in Staffordshire, on the moor lands in the north of that county, and on the moors in Derbyshire, Yorkshire, and northwards to Scotland, also on Bagshot Heath, Salisbury Plain, the heaths and wastes in Sussex, Hampshire, and Dorsetshire, and in many other counties in England, and also in Scotland and Wales. In that paper I suggested, that information of very great value on the subject of planting, might be obtained from noblemen and grentlemen to whom the Society had given medals and premiums for planting trees, if they would communicate to the Society their subsequent observations on such plan-

\footnotetext{
* From Transactions of the Society for the Encouragement of Arts, Manufaceures, and Commerce, for 1809. + See Philosophical Magazine, vol, xxxiii.
} 
tations; but it is to be regretted that the Society have not yet received any communications on the subject.

I have been solicited to republish my tables, \&x. by different gentlemen, who I have reason to believe are very competent to judge of them, and I have in consequence several additional tables in forwardness with this view; but, previous to such publication, I wish to be furnished with a great variety of facts as to the growth of timber, and the management of plantations; and I shall feel much obliged to any persons who will have the goodness to send me their observations and statements of facts, respecting the growtb and management of plantations; or, if they prefer it, they may send them to you at the Society of Arts, \&c. The names of those who serd such statements will be either given or suppressed as may be requested.

I will recapitulate nearly in the words of my former communication, several particulars on which information is wanted. It would, for instance, be desirable to have the nature of the soil and under strata described, on which plantations have been made; its value per acre; the mode in which it was prepared for planting; the sorts of trees planted thereon, and which of them were found best suited thereto; the distances at which the trees were first planted; at what periods they were thinned, and how many cut out at each thinning; and their measure and value; the present height, distance, measure and value of the trees now growing on an acre; what distances are found most advantageous; also to what proportion of their heights they should be pruned up, and the best and most expeditious mode of performing the uperation.

Great loss is frequently sustained by omitting to thin plantations properly, and in due time, but I am not in possession of facts to calculate with accuracy what this loss may be; I will however venture to give a short statement of some calculations I have made, as to the loss that would now be sustained by letting trees grow to a great age.

In Miller's Gardener's Dictionary, it is stated that in a fall of oak timber in Lord Bagot's woods, Mr. Marshall counted the rings of one tree, which was sound at the butt, and found the number to be about 900 . Its bole was 92 feet long, and 108 inches in circumference in the middle. Its contents 110 feet, which at $2 s$. amounts to $11 l$. I think it was last year, that a fine sound oak-tree was cut down, between Shrewsbury and Oswestry in Shropshire, of 300 years of age, and sold by auction for $52 l .5 s$. - And under my direction, many oak trees were cut down, some 
years ago, that could not be less than 300 , and some of them probally 400 years of age, and even more. In Hunter's Evelyn's Silva is given the circumference of 10 trees, and not one of which was probably less than 500, and some of them probably 1000 , years old.

Lord Bagot's tree of 200 years old, above mentioned, would, at the present price of $3 s$. a foot, be worth $16 \mathrm{l}$. 10 s. Supposing that $3 s$. a foot should continue to be the price of oak-timber for the next 200 years, we will inquire what sum might be raised by growing four oak-trees in succession, upon the same spot of ground, each tree to be cut down when 50 years of age, and that their boles should be of the same length as that of Lord Bagot's, viz. 22 feet.

I fix on fifty year's of age, as being convenient for my calculation; and nearly the most profitable period at which to cut down trees of 22 feet bole, which have grown at the medium rate of one inch in circumference, and 12 inches in height anuually.

After its $52 \mathrm{~d}$ year, such a bole ceases increasing, after the rate of 5 per cent. per annum* : but the whole tree, including the top part above the bole, may continue increasing after that rate until its 6 ist year + .

I do not fix on 50 years of age as being the most profitable age at which to cut down trees; probably 60 or 70 years of age would in some instances be preferable. Supposing an oak-tree has increased as above mentioned, its bole of 22 feet would, at 50 years of age, measure 39 inches in circumference at the middle, and one-fourth of this, namely 930 inches, squared and multiplied into 22 feet, its length gives 14 feet 6 incbes for its contents, which at $3 s$. a foot, its present value, amounts to $2 l .3 s$. $6 d$. Supposing $2 l$. $3 s$. $6 d$. to be the value of each of the four trees of 50 years of age, grown in succession upon the same spot of ground, in the period of 200 years, we will calculate to what the three first trees would amount, if their value was placed out at compound interest, for the respective terms of 150 , of 100 , and of 50 years.

£. s. $d$.

$2 \quad 3 \quad 6$ Accumulating during 150 years, at

$$
\text { £. s. } d \text {. }
$$

5 per cent. per annum compound interest, will amount to $-3,280 \quad 0 \quad 0$

$2 \quad 36$ Accumulating as above for 100 years, would amount to - $286 \quad 0 \quad 0$

* See Table 12 of a bole of 24 feet, in the 26 th volume of the Society's Transactions, page 68 .

$\uparrow$ Sec nyy first Table in ditto, page 49. 
E.s. $d$.

$2 \quad 36$ Accumulating as above for 50 years, will amount to

Add the value of the tree to be cut down at the end of 200 years

Total amount in 200 years -
\&. s. d.

$24 \quad 0 \quad 0$

236

And carrying forward this calculation, the total amount of the produce in 300 years would. amount to - $\quad £ .472,408$ o 0

In former times, when the value of oak-woods was estimated by the number of hogs their acorns would fatten, the great age of trees would be of small consideration; but in the present times, I am persuaded, that if gentlemen who have many trees standing of the age of 150 years and upwards, would give this subject its due consideration, they will be aware of the immense loss to which they are voluntarily subjecting themselves.-And this great loss is much to be regretted, in a political point of view, especially as the produce of this island is insufficient for its necessary consumption.

My motives for troubling you with this hasty production. are, to promote the good of the public, by endeavouringe to persuade gentlemen to bring forward well ascertained facts, respecting the most profitable management of growing timber trees, and to induce them to investigate, with accuracy, this very curious and important subject. If you think it is likely to have those effects, I shall thank you to lay this paper before the Society of Arts, \&c. for their consideration.

No. 99, High Holbcrn,

I am, sir, your obedient servant,

Charles Waistell. Oct. 1809 .

LXIV. A List of about Five Hundred Collieries in and near to Derlyshire. By Mr. John E $\mathrm{AREx}$, Mineralogical Surveyor.

$$
\text { To Mr. Tillocil. }
$$

SIR, I Incrose a list, of such collieries as $\mathrm{I}$ have either visited or obtained information concerning, in the course of my recent examination of the county of Derby, and the borders of the seven adjacent counties. Should you deem 